International Journal of Business Management and Economic Review

Vol. 4, No. 05; 2021

ISSN: 2581-4664

\title{
TESTING THE STRUCTURAL EFFECT OF TOURISM DESTINATION IMAGE AND PLACE ATTACHEMENT ON TOURIST LOYALTY THROUGH TOURIST SATISFACTION TO WEH ISLAND: THE DIFFERENCE BETWEEN FIRST-VISIT TOURISTS AND REPEAT-VISIT TOURISTS
}

\author{
Muhammad Teguh Aulia, Permana Honneyta Lubis and Syafruddin Chan \\ Management Department, Universitas Syiah Kuala, Indonesia \\ http://doi.org/10.35409/IJBMER.2021.3309
}

\begin{abstract}
Tourists who come to one area only consist of two types, namely new tourists and old tourists who come back. The more tourists who come again and again, then it is a good indication for a tourist destination because it means that he is satisfied and wants to come back again. This concept is known as loyalty. The purpose of this study was to see the effect of the image of tourist destinations and place attachments on tourist loyalty through satisfaction, with frequency of visit as moderating variables in Weh Island tourist destinations, Indonesia. The population in this study were all tourists who came and visited Weh Island. The expected number of samples is at least 150 samples. The results showed that of the 5 direct hypotheses, all of them were accepted and significant because they had a CR value greater than or equal to and a $\mathrm{P}$ value of 0.05 , which met the minimum requirements of the accepted hypothesis. The results of testing the mediation hypothesis that the role of satisfaction of tourists when visiting Weh Island is partially mediated, and the results of the moderation testing, namely the visit frequency for the full model prove that the difference is not significant between first-visit tourist and repeat-visit tourist. In other words, there is no real difference between tourists who come to Weh Island for the first time and those who have come more than once in responding to all marketing stimuli contained in the model towards their level of loyalty. This implies that tourist destination managers can apply a model of increasing tourist loyalty with strategies to improve the image of tourism destinations and increase the sense of place attachment of tourists, so that there will be an increase in tourist satisfaction which acts as a partial mediator and will subsequently have an impact in the form of increasing tourist loyalty, without having to pay attention to the variable first visit tourist or repetition visit tourist.
\end{abstract}

Keyword: Tourism Destination Image, Place Attachment, Tourist Loyalty, Tourist Satisfaction, Visit Frequency.

\section{INTRODUCTION}

Aceh, one of province in Indonesia, has long promoted itself as a tourist destination, especially what the Aceh Tourism Office has been actively doing in creating a calendar of events, both on a local, national, and international scale. At the same time, Aceh is also present in various tourism exhibition events held in various countries, in an effort to promote Aceh as a 


\section{International Journal of Business Management and Economic Review}

Vol. 4, No. 05; 2021

ISSN: 2581-4664

tourist destination. One of the tourist destinations in the province of Aceh that is being heavily promoted is Weh Island (Sabang).

Weh Island is known as a marine tourism destination. Not only because of the natural beauty under the sea. But there are also natural forests that are used as conservation areas, so that biodiversity is maintained, both the number of plants and animals that live in it. For diving sports lovers, Weh Island has long been one of the areas that have challenging diving spots. The island which is located at $05^{\circ} 50^{\prime}-05^{\circ} 54^{\prime}$ North Latitude and $95^{\circ} 14^{\prime}-95^{\circ} 17^{\prime}$ East Longitude with an area of $153 \mathrm{~km}^{2}$ has very diverse biodiversity. Rubiah Island, which is part of Weh Island, has been designated a Marine Park. This is an attraction for local and foreign tourists to visit.

As we know, the number of tourists who come to one area only consists of two types. Namely new tourists and old tourists who come back. The more tourists who come again and again, then it is a good indication for a tourist destination because it means that he is satisfied and wants to come back again. This concept is known as loyalty.

To find out if there is a problem with the loyalty of tourists who come to Weh Island, the authors conducted a preliminary survey of 20 tourists who have come to Weh Island. The results of this survey indicate that the loyalty of tourists to Weh Island has not been as expected, of course, this is a phenomenon that needs to be searched for solutions.

\section{LITERATURE REVIEW}

\section{Tourism Destination Image}

(Prayag \& Ryan, 2012) argued that tourist destinations are a special zone where elements such as local culture, social systems, ecology, and the same economic atmosphere with political backgrounds can influence public comments either positively or negatively. A destination image is not created by itself but with the thoughts or views of a tourist regarding the destination (Hamjah, 2015). Guidelines override the development of destination imagery based on rationality and emotionality as well as a mixed result of some measures (Lim \& Kim, 2020). The main importance and value assigned to each destination attribute. The image of a destination is assessed by the attributes of the energy source and the energy of attraction that wants to motivate a person to visit the destination (Fadiryana \& Chan, 2019).

\section{Place Attachment}

(Lim \& Kim, 2020) revealed that place attachment is as a result of human emotions in the environment, values and unique experiences of people, to form self-evidence in which we orient ourselves to the world. Another comment said place attachment is a space that has meaning through knowledge of a place, as well as a bond of feelings or emotions between humans and their environment (Prayag, Chen, \& Chiappa, 2018).

\section{Tourist Satisfaction}

For (Lee, Jeon, \& Kim, 2011) stated consumer satisfaction is the customer reactions to the assessment of the mismatch experienced between expectations and the actual performance of the service. On the other hand, (Ramseook-Munhurrun, Seebaluck, \& Naidoo, 2015) said satisfaction is the level of a person's feelings after equating the performance/results he feels with his expectations. The approach put forward by Kotler and Oliver emphasizes that satisfaction is an evaluation of what a person has obtained. 
International Journal of Business Management and Economic Review

Vol. 4, No. 05; 2021

ISSN: 2581-4664

\section{Tourist Loyalty to Destination}

Loyalty is the unchanging behavior of tourists to always come to tourist objects. (Rahmayanti, Lubis, \& Utami, 2019) said the description of customer loyalty is not only seen from the transaction or the umpteenth purchase (repeat customer). (Chiu, Zeng, \& Cheng, 2016) revealed the results of an assessment will raise an assumption of value and play a role in this matter. Next, tourists want to calculate which offers will share the highest value and satisfaction.

\section{Research paradigm}

Paradigm or bond between concepts (variables) in this research can be illustrated in Figure 1 below.

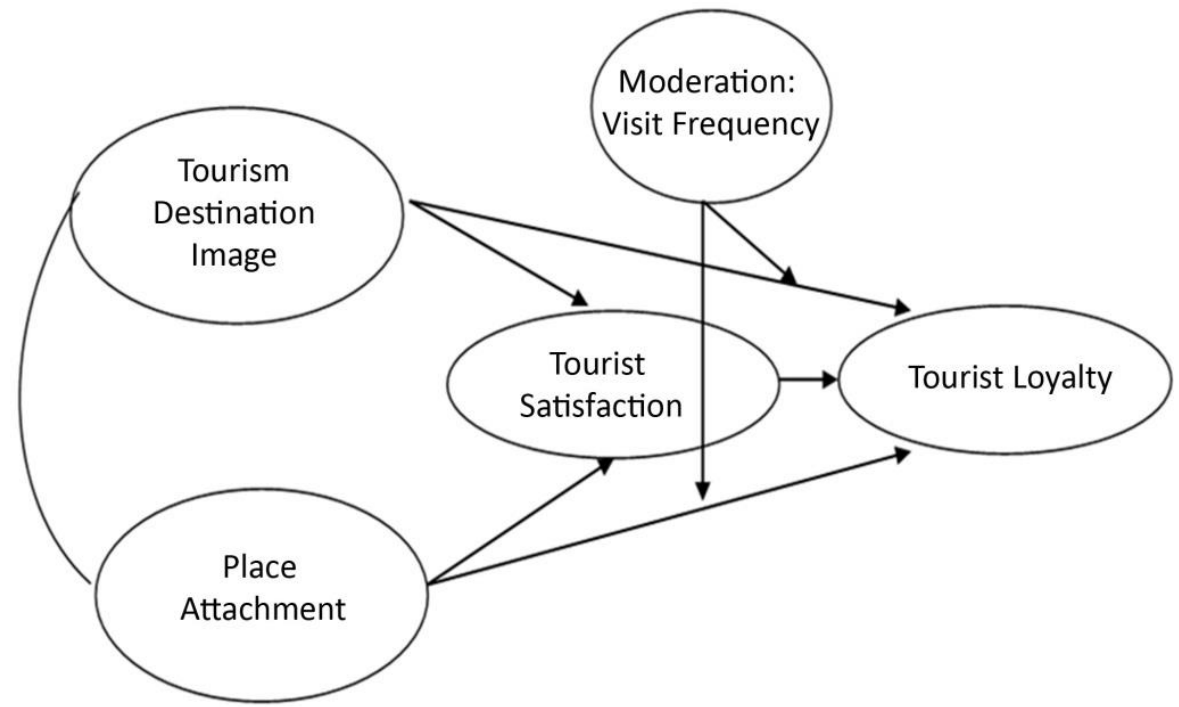

Figure 1. Research Paradigm

\section{Hypothesis}

H1: destination image affects tourist visit satisfaction.

$\mathrm{H} 2$ : destination image affects tourist loyalty

H3: place attachment affects tourist satisfaction

H4: place attachment affects tourist loyalty

H5: tourist satisfaction affects tourist loyalty

H6: destination image affects tourist loyalty through tourist satisfaction

H7: place attachment affects tourist loyalty through tourist satisfaction

H8: there is a real difference between First-Visit and Repeat-Visit on the influence of tourist destination image on tourist loyalty

H9: there is a real difference between First-Visit Tourist and Repeat-Visit Tourist on the influence of place attachments on tourist loyalty

\section{RESEARCH METHOD}

\section{Location and Object of Research}

This research was conducted on tourists who come and visit Weh Island. The object of this 
Vol. 4, No. 05; 2021

ISSN: 2581-4664

research was all marine tourists, especially divers who come to visit Sabang. The variables of this study in accordance with the phenomena raised were Destination image, Place Attachment, Tourist Loyalty and Tourist Satisfaction. There was also one moderator variable that was visit frequency which was appointed as a differentiator for those who have visited for the first time and who have visited more than once.

\section{Sampling}

The population in this study were all tourists who came and visited Weh Island. As for the number of indicators in this study as many as 20 indicators, so a minimum of $20 \times 5$ or 100 samples is needed. The number of good samples according to MLE ranges from 100-200 samples. Therefore, the expected sample size is at least 150 samples.

\section{Data analysis method}

Data processing obtained in the field is done by using equation modeling techniques, namely multivariate statistical analysis techniques to be able to analyze not only the influence between variables but also the relationship between variables and their respective indicators. The criteria for acceptance of Ha are Critical Ratio (CR) $>1.96$ and the value of Probability $(\mathrm{P})<0.05$.

\section{RESULT}

\section{Loading Factor with measurement test}

Testing the validity of loading factors can be seen in the following figure and table:

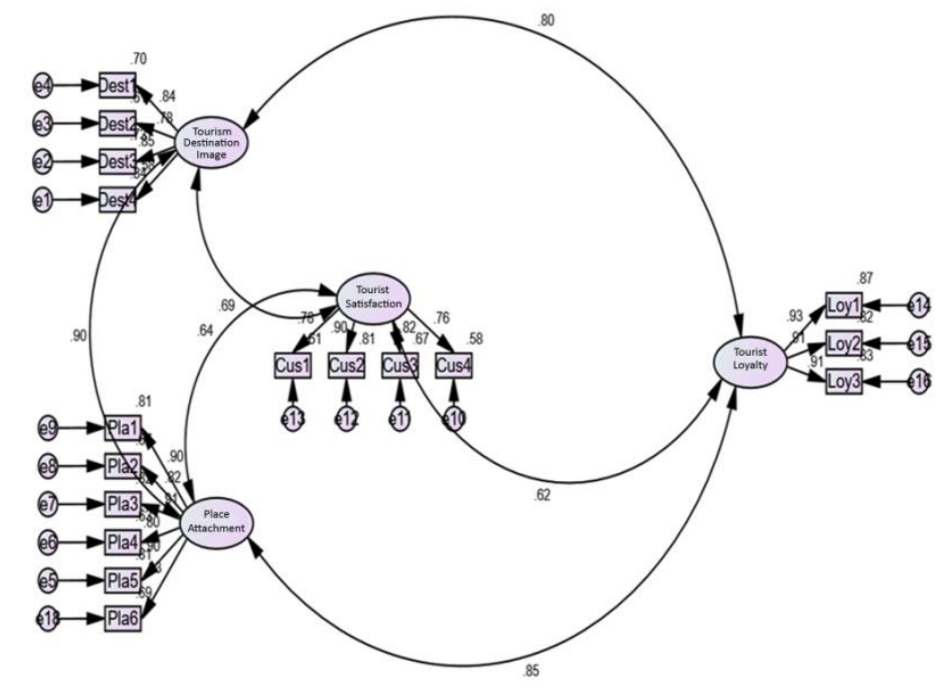

Figure 2. Loading Factor

Measurement test results indicate that several indicators of the research variables have a loading factor value below 0.5 and have met the requirements for further processing because it has a loading factor value $>0.5$. 


\section{Table 1. The goodness of Fit Criteria Table}

\begin{tabular}{|l|l|l|l|}
\hline Size Index Criteria & Cut-off Value & $\begin{array}{l}\text { Analysis } \\
\text { Results }\end{array}$ & Model Evaluation \\
\hline CMIN / DF & $<2$ & 1,993 & Good \\
\hline RMSEA & $\leq 0.08$ & 0.076 & Good \\
\hline IFI & $\geq 0.90$ & 0.944 & Good \\
\hline
\end{tabular}

\section{Structural Model for Direct Hypothesis Testing}

The results of the structural testing carried out have produced the information needed to answer the previously built hypothesis whether it is proven or not. Figure 3 below illustrates the influence between variables:

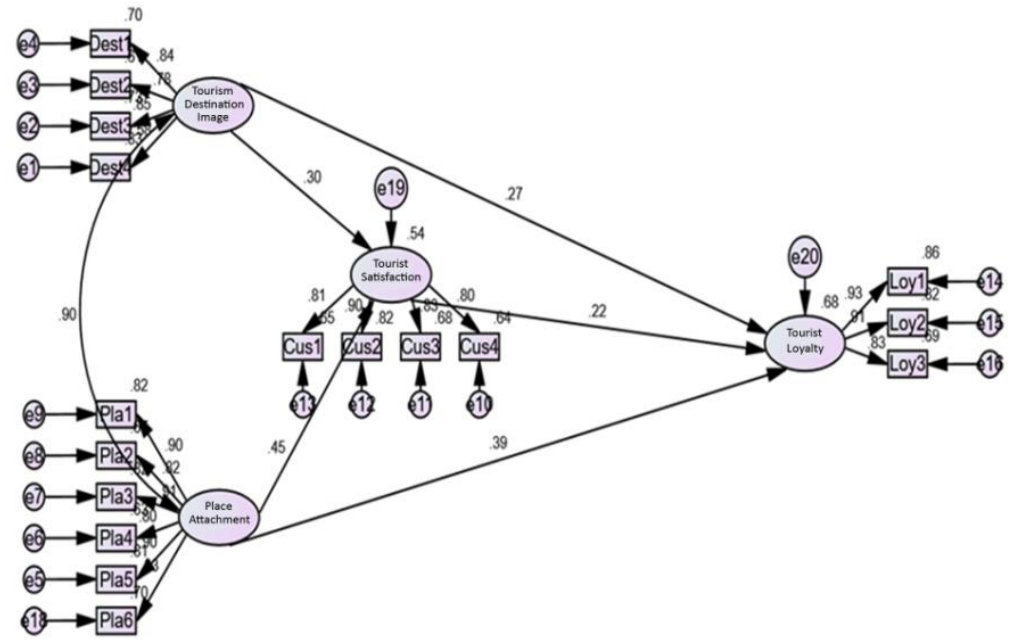

Figure 3. Structural Equation Model

Based on Figure 3, it can be explained that the influence of each variable, namely Destination Image, Place Attachment, Tourism Satisfaction, and Tourism Loyalty. An overview of all hypothesis testing along with the results can be seen in Table 2 below:

\section{Table 2. Hypothesis Conclusion}

\begin{tabular}{|c|l|l|l|l|}
\hline No. & Hypothesis & $\begin{array}{l}\text { CR Cut } \\
\text { off }>\mathbf{1 . 9 6}\end{array}$ & $\begin{array}{l}\text { P-Value } \\
\text { Cut off } \\
\mathbf{< 0 . 0 5}\end{array}$ & $\begin{array}{l}\text { Informati } \\
\text { on }\end{array}$ \\
\hline 1 & $\begin{array}{l}\text { Destination Image in affecting Tourist } \\
\text { Satisfaction }\end{array}$ & 1.966 & .049 & .304 \\
\hline 2 & $\begin{array}{l}\text { Destination Image in affecting tourist } \\
\text { loyalty }\end{array}$ & 1.968 & .048 & .268 \\
\hline
\end{tabular}


Vol. 4, No. 05; 2021

ISSN: 2581-4664

\begin{tabular}{|c|l|l|l|l|}
\hline \hline No. & Hypothesis & $\begin{array}{l}\text { CR } \\
\text { off }>\mathbf{1 . 9 6}\end{array}$ & $\begin{array}{l}\text { P-Value } \\
\text { Cut } \mathbf{< 0 . 0 5}\end{array}$ & $\begin{array}{l}\text { Informati } \\
\text { on }\end{array}$ \\
\hline 3 & $\begin{array}{l}\text { place attachment in affecting tourist } \\
\text { satisfaction }\end{array}$ & 3.040 & .002 & .446 \\
\hline 4 & $\begin{array}{l}\text { place attachment in affecting tourist } \\
\text { loyalty }\end{array}$ & 3.032 & .001 & .393 \\
\hline 5 & $\begin{array}{l}\text { tourist satisfaction in affecting tourist } \\
\text { loyalty }\end{array}$ & 2.798 & .005 & .224 \\
\hline
\end{tabular}

It can be seen from the 5 direct hypotheses that there are all hypotheses that have a significant effect because they have met the minimum requirements of the accepted hypothesis. In other words, other independent variables, namely destination image and place attachment on tourist satisfaction and loyalty can be well received as long as the independent variables can be increased by tourism actors on Weh Island.

\section{Indirect Hypothesis Testing}

The conclusion of the indirect hypothesis is the indirect hypothesis, namely the Influence of Destination Image on Tourism Loyalty through Tourism Satisfaction and the Effect of Place Attachment on Tourism Loyalty through Tourism Satisfaction.

\section{Table 3. Indirect Effect Hypothesis Conclusion}

\begin{tabular}{|l|l|l|l|l|l|}
\hline No. & Indirect Hypothesis & $\begin{array}{l}\text { P-Value } \\
<0.05\end{array}$ & Beta & $\begin{array}{l}\text { Informatio } \\
\mathrm{n}\end{array}$ & $\begin{array}{l}\text { Role } \\
\text { Mediation }\end{array}$ \\
\hline 1 & $\begin{array}{l}\text { Destination Image in affecting } \\
\text { Customer Loyalty through Customer } \\
\text { Satisfaction }\end{array}$ & 0.033 & $06.8 \%$ & Accepted & $\begin{array}{l}\text { Partial } \\
\text { Mediating }\end{array}$ \\
\hline 2 & $\begin{array}{l}\text { Place Attachment in affecting } \\
\text { Customer Loyalty through Customer } \\
\text { Satisfaction }\end{array}$ & 0.019 & $10.0 \%$ & Accepted & $\begin{array}{l}\text { Partial } \\
\text { Mediating }\end{array}$ \\
\hline
\end{tabular}

Testing the multi-group moderation hypothesis that compares first-time tourists to Weh Island with tourists who have come more than once. The results are as shown in Table 4 below:

\section{Table 4. Full Multi-group Model}

Assuming model Unconstrained to be correct:
\begin{tabular}{|l|cccrrrr|}
\hline \multirow{2}{*}{ Model } & \multirow{2}{*}{ DF } & CMIN & P & $\begin{array}{r}\text { NFI } \\
\text { Delta-1 }\end{array}$ & $\begin{array}{r}\text { IFI } \\
\text { Delta-2 }\end{array}$ & $\begin{array}{r}\text { RFI } \\
\text { rho-1 }\end{array}$ & $\begin{array}{r}\text { TLI } \\
\text { rho2 }\end{array}$ \\
\hline Structural weights & 5 & 6.902 & .228 & .003 & .003 & -.001 & -.001 \\
\hline
\end{tabular}

From the table above, because the P-value of the multigroup comparison model between two groups is $0.228>0.05$, it can be said that the difference is not significant. In other words, there is no real difference between tourists who come to Weh Island for the first time and those who 


\section{International Journal of Business Management and Economic Review}

Vol. 4, No. 05; 2021

ISSN: 2581-4664

have come more than once in responding to all marketing stimuli contained in the model towards their level of loyalty.

\section{CONCLUSION}

From the result we can conclude the analysis as follows.

1. From the results of research and descriptive hypothesis testing, it can be seen that the significance level with alpha $5 \%$ is all below the 0.05 number so it can be concluded that all the variables in this study, namely Destination Image, Place Attachment, Customer Satisfaction, and Customer Loyalty are good.

2. In the CFA test, it can be seen from the table above that there is 1 indicator that does not meet the requirements because it has a loading factor number below that is required, namely 0.5 . So that must be eliminated. After eliminating, all the indicators involved in this study are said to be valid, because they have met the validity requirements.

3. Of the 5 direct hypothesis testing, namely the effect of the image of tourist destinations on satisfaction, the image of tourist destinations on tourist loyalty, place attachments on tourist satisfaction, place attachments on tourist loyalty, and tourist satisfaction on tourist loyalty, all show positive and significant results.

4. Likewise with the indirect effect, namely the image of tourist destinations on tourist loyalty through tourist satisfaction and place attachments on tourist loyalty through tourist satisfaction, the results are also positive and significant.

5. In the comparison model, the difference between the first visit group and the frequency visit was not significant, which means that there was no significant difference between these two groups.

Several recommendations can be provided from the analysis result.

1. When viewed from the 3 existing determinant variables, it can be seen that the Place Attachment has made the biggest contribution to the increase in tourist loyalty. These findings can be used as a guide in solving problems related to tourist loyalty.

2. Furthermore, if we look in more detail, it turns out that the indicators that also play a role in increasing the level of Place Attachment among tourists as customers in encouraging friends or relations to make purchases or visit this Weh Island tourist destination, what needs to be maintained is talking about marine tourism, people will imagine snorkeling and diving on Weh Island. We can see that these two tourist attractions make a big contribution to make people want to come back to Weh Island again.

3. If we see from the coefficient of these two indirect influences, it can be seen that the influence of Place Attachment's influence on Customer Loyalty through Customer Satisfaction is stronger than the Effect of Destination Image on Customer Loyalty through Customer Satisfaction, because it has a greater magnitude, namely 0.100 compared to 0.068 Because they are backed up by indirect influences which are all significant, then these two indirect effects have a mediation variable customer satisfaction which functions as partial mediating.

4. Furthermore, because there is no real difference between tourists who come to Weh Island for the first time and those who have come more than once in responding to all marketing stimuli contained in the model towards their level of loyalty. So the stimulants that must be done to the two groups of tourists do not need to be differentiated. This is 
reinforced by more detailed findings on the examination of each pathway, namely pathways 1 to 5 contained in the model, which also did not show significant differences between these two groups.

5. In the future, further researchers can develop this tested model by adding variables such as attractiveness and promotion mix.

\section{REFERENCES}

Chiu, W., Zeng, S., \& Cheng, P. S.-T. (2016). The influence of destination image and tourist satisfaction on tourist loyalty: a case study of Chinese tourists in Korea. International Journal of Culture, Tourism and Hospitality Research, 10(2), 223-234. https://doi.org/https://doi.org/10.1108/IJCTHR-07-2015-0080

Fadiryana, N. A., \& Chan, S. (2019). Pengaruh Destination Image dan Tourist Experience Terhadap Revisit Intention yang Dimediasi Oleh Perceived Value Pada Destinasi Wisata Halal di Kota Banda Aceh. Jurnal Manajemen Inovasi, 10(2), 1-23. https://doi.org/https://doi.org/10.24815/jmi.v10i2.15994

Hamjah, N. (2015). Pengaruh Periklanan, Pameran Dan Event Terhadap Peningkatan Kesadaran Wisatawan Dan Dampaknya Pada Minat Berkunjung Ke Destinasi Wisata Religi Di Aceh. Univeristas Syiah Kuala.

Lee, S., Jeon, S., \& Kim, D. (2011). The impact of tour quality and tourist satisfaction on tourist loyalty: The case of Chinese tourists in Korea. Tourism Management, 32(5), 1115-1124. https://doi.org/https://doi.org/10.1016/j.tourman.2010.09.016

Lim, S. H., \& Kim, D. J. (2020). Does Emotional Intelligence of Online Shoppers Affect Their Shopping Behavior? International Journal of Human-Computer Interaction, 36(14), 13041313. https://doi.org/https://doi.org/10.1080/10447318.2020.1739882

Prayag, G., Chen, N. (Chris), \& Chiappa, G. Del. (2018). Domestic tourists to Sardinia: motivation, overall attitude, attachment, and behavioural intentions. Anatolia, 29(1), 84-97. https://doi.org/https://doi.org/10.1080/13032917.2017.1387583

Prayag, G., \& Ryan, C. (2012). Antecedents of Tourists' Loyalty to Mauritius: The Role and Influence of Destination Image, Place Attachment, Personal Involvement, and Satisfaction. Journal of Travel Research, 51(3), 342-356. https://doi.org/https://doi.org/10.1177/0047287511410321

Rahmayanti, C., Lubis, P. H., \& Utami, S. (2019). Determinant Of Purchasing Decision And Loyalty Of The Consumer Of Wardah Cosmetic Productsin Banda Aceh, Indonesia. International Journal of Business Management and Economic Review, 2(6), 60-67. https://doi.org/http://doi.org/10.35409/IJBMER.2019.2428

Ramseook-Munhurrun, P., Seebaluck, V. N., \& Naidoo, P. (2015). Examining the Structural Relationships of Destination Image, Perceived Value, Tourist Satisfaction and Loyalty: Case of Mauritius. Procedia - Social and Behavioral Sciences, 175, 252-259. https://doi.org/https://doi.org/10.1016/j.sbspro.2015.01.1198 